\title{
Feasibility of Recovering Energy from Municipal Solid Waste to Generate Electricity
}

\author{
Ari Darmawan Pasek, Kilbergen W. Gultom \& Aryadi Suwono \\ Faculty of Mechanical and Aerospace Engineering, \\ Institut Teknologi Bandung, Jalan Ganesa 10, Bandung 40132, Indonesia \\ Email: aripasek@gmail.com
}

\begin{abstract}
Population growth and economic development in Indonesia have increased the production of municipal solid waste (MSW) in many big cities, causing sanitary problems. The (MSW) disposal problem can be solved by applying an appropriate technology that can reduce the volume of the waste effectively and efficiently. Waste-to-Energy (WTE), or Energy-from-Waste $(\mathrm{EFW})$, is one of the most effective and efficient technologies for reducing the waste volume. Energy recovered from the waste can be used for thermal or electricity generation. This paper deals with a feasibility study of utilizing MSW for generating electricity. A survey and investigation of waste characteristics, including waste composition, chemical and physical composition, and heating value, were carried out for typical Bandung MSW. An average heating value of $1500 \mathrm{kcal} / \mathrm{kg}$ can be expected from pre-treated MSW to be used as a fuel for direct combustion in a WTE plant. A typical design for a small-scale WTE plant is shown in this paper and also an energy analysis is provided. Approximately $800 \mathrm{~kW}$ of electric power can be generated from 50 tonnes of MSW per day.
\end{abstract}

Keywords: boiler design; direct combustion; incinerator; municipal solid waste; power plant; renewable energy; Waste to Energy Plant.

\section{Introduction}

The amount of municipal solid waste (MSW) in many cities in Indonesia has increased significantly due to the population growth and economic development. Open dumping, the only method currently used for the final disposal of MSW, faces many difficulties due to the limited area available and resistance from surrounding communities. The MSW disposal problem can be solved by applying an appropriate technology that can reduce the waste volume effectively and efficiently. Moreover, the technology must be economically sustainable, and use a relatively small area over a long period of time. Waste-toEnergy (WTE), or Energy-from-Waste, is one of the most effective and efficient technologies for reducing the waste volume. Energy recovered from the waste can be used for thermal or electricity generation. Furthermore, open dumping of MSW generates green house gases such as methane and other poisonous gases when it is unintentionally burned. Hence, the utilization of a WTE plant could

Received May $30^{\text {th }}, 2011,1^{\text {st }}$ Revision March $3^{\text {rd }}, 2012,2^{\text {nd }}$ Revision March $7^{\text {th }}, 2013$, Accepted for publication April $18^{\text {th }}, 2013$.

Copyright (C) 2013 Published by ITB Journal Publisher, ISSN: 2337-5779, DOI: 10.5614/j.eng.technol.sci.2013.45.3.3 
also reduce the green house gases emitted by dumped MSW. The application of WTE for removing green house gases is approved by UNFCCC's document AM0025 and is eligible for the Clean Development Mechanism (CDM) scheme [1].

This paper deals with a feasibility study of utilizing MSW for generating electricity. The study covers only the technical aspect of the thermal analysis. A series of surveys were carried out to find out the composition of MSW in the Bandung area, followed by proximate, ultimate and heating value tests of the most important waste components. Since some of the components are taken for recycling and reuse, only the remaining components can be used as fuel for a WTE plant. The chemical and physical as well as the heating value of these remaining wastes were evaluated for their use as a fuel in the furnace and boiler of a small-scale WTE plant. The objectives of this study were to investigate the characteristics of typical tropical MSW and the possibility of applying this tropical MSW in a WTE plant. This paper provides information about the typical characteristics of MSW from tropical cities and a basic design for a small-scale WTE plant using tropical MSW.

\section{Methodologies}

The study started with a survey of MSW components. Municipal solid waste in many cities in Indonesia mainly comes from homes, public facilities, streets, offices, malls, and markets/supermarkets. Citizens are responsible for disposal of domestic waste to temporary collection/disposal areas (TPS), and the municipal authorities are responsible for its transfer from the temporary disposal area to the final disposal area (TPA). The MSW survey was carried out at 23 TPSs and TPAs in the Bandung area. From each TPS and TPA $3 \mathrm{~m}^{3}$ MSW sample was separated into several component categories such as organic materials, food, glass, metal, recyclable plastic, non recyclable plastic, rubber, paper, foam, textile, electronics and other wastes. The analyses were carried out on eight consecutive days. The heating value, ultimate and proximate analysis was then done for each waste component. The tests were done at TekMIRA (Pusat Penelitian dan Pengembangan Teknologi Mineral dan Batu Bara, Kementerian Energi dan Sumber Daya Mineral, Bandung, Indonesia). The testing methodology/codes are summarized in Table 1.

Some valuable waste components, such as recyclable plastic, paper, electronics, glass, and metal, are often selected and taken by informal collectors from TPS's and TPA's, hence only the remaining waste components can be incinerated in the WTE plant. The combined properties of these remaining waste components were calculated to predict their combined ultimate, proximate and heating value. These properties were then used for an energy analysis and the design of a 
furnace and boiler. The energy analysis was done using the Cycle Tempo software application [2] in order to find the operating conditions for the main components of the WTE steam power plant. The operating conditions were calculated with known heat input in the boiler. The heat input was calculated from the amount of MSW utilized and the predicted heating value. Then, the dimensions of the furnace and boiler were calculated using the FireCad software application [3]. The calculations were iterated to find the operating conditions that give maximum power output.

Table 1 Standards used for testing at TekMIRA.

\begin{tabular}{ll}
\hline \multicolumn{1}{c}{ Component } & \multicolumn{1}{c}{ Standard } \\
\hline Moisture & ISO 11722 ASTM D.3173 \\
Ash & ISO 1171 ASTM D.3174 \\
Volatile matter & ISO 562 \\
Fixed carbon & 100\%-M-Ash-VM \\
Carbon & ISO 625 ASTM D.3178 \\
Hydrogen & ISO 625 ASTM D.3178 \\
Nitrogen & ISO 332 ASTM D.3179 \\
Sulfur & ASTM D.4239 \\
Oxygen & 100\%-C-H-N-S-Ash \\
Calorific value & ASTM D.5865 \\
\hline
\end{tabular}

\section{Waste Characteristics}

The results of the survey of the composition of the waste from the TPSs are shown in Table 2. The table shows the MSW composition in mass and volume fraction respectively.

Table 2 MSW Composition.

\begin{tabular}{lcc}
\hline \multicolumn{1}{c}{ Component } & $\begin{array}{c}\text { Mass } \\
\text { Fraction }(\boldsymbol{\%})\end{array}$ & $\begin{array}{c}\text { Volume Fraction } \\
(\boldsymbol{\%})\end{array}$ \\
\hline Organic matter & 35.58 & 44.51 \\
Food waste & 22.58 & 11.75 \\
Paper & 13.67 & 14.24 \\
Recyclable plastic & 7.06 & 15.30 \\
Non recyclable Plastic & 5.69 & 4.91 \\
Glass & 3.19 & 2.58 \\
Metal & 3.31 & 1.61 \\
Textile & 1.94 & 0.92 \\
Rubber & 0.68 & 0.36 \\
Styrofoam & 0.25 & 0.83 \\
Electronic waste & 0.56 & 0.4 \\
Others & 5.49 & 2.59 \\
\hline
\end{tabular}


The results of the proximate, ultimate, and heating value tests of several waste components are shown in Tables 3 and 4. The tested samples were air-dried based (adb) samples. From these figures it can be seen that the MSW components were dominated by the element carbon. However, most of the carbon was in volatile matter, as the amount of fixed carbon was less than $20 \%$. The higher heating value (HHV) of several of the components is significantly higher under adb conditions, which indicates a high possibility of being utilized as fuel.

Table 3 Proximate analysis result of the MSW components.

\begin{tabular}{lcccc}
\hline \multicolumn{1}{c}{ Sample Mark } & $\begin{array}{c}\text { Moisture } \\
\text { \%, adb }\end{array}$ & $\begin{array}{c}\text { Ash } \\
\boldsymbol{\%}, \mathbf{a d b}\end{array}$ & $\begin{array}{c}\text { Volatile } \\
\text { Matter } \\
\mathbf{\% ,}, \mathbf{a d b}\end{array}$ & $\begin{array}{c}\text { Fixed } \\
\text { Carbon } \\
\mathbf{\% ,}, \mathbf{a d b}\end{array}$ \\
\hline Leaf & 10.78 & 7.28 & 62.27 & 19.67 \\
Food waste & 8.48 & 4.51 & 72.52 & 14.49 \\
Wood & 8.82 & 7.15 & 66.64 & 17.39 \\
Thick Paper & 7.56 & 5.40 & 75.01 & 12.03 \\
Writing paper & 6.42 & 11.77 & 75.13 & 6.68 \\
Duplex paper & 20.64 & 9.54 & 61.02 & 8.80 \\
Box paper & 6.81 & 8.44 & 75.34 & 9.41 \\
PVC & 0.28 & 4.96 & 79.83 & 14.93 \\
Bottle plastic & 0.63 & 0.62 & 89.32 & 9.43 \\
Hard plastic & 0.52 & 0.41 & 89.90 & 9.17 \\
Wrapping plastic & 0.31 & 3.54 & 89.76 & 6.39 \\
Toy plastic & 0.20 & 1.70 & 98.09 & 0.01 \\
PP plastic & 0.07 & 0.66 & 99.23 & 0.04 \\
OPP plastic & 0.76 & 0.18 & 99.06 & 0.00 \\
Container plastic & 0.20 & 1.49 & 98.05 & 0.26 \\
HD plastic & 0.06 & 0.41 & 99.53 & 0.00 \\
Syringe & 0.36 & 0.69 & 98.48 & 0.47 \\
PE plastic & 0.03 & 0.41 & 99.56 & 0.00 \\
Plastic bag & 0.12 & 1.85 & 98.03 & 0.00 \\
Medical plastic & 0.21 & 0.46 & 94.33 & 0.00 \\
Plastic cup & 0.18 & 0.79 & 99.03 & 0.00 \\
Styrofoam & 1.45 & 0.84 & 96.75 & 0.96 \\
Synthetic & 1.54 & 14.97 & 70.27 & 13.22 \\
Waste sample I & 5.80 & 26.77 & 54.98 & 12.45 \\
Waste sample II & 33.08 & 8.98 & 48.66 & 9.28 \\
Textile & 1.23 & 0.42 & 89.07 & 9.28 \\
Rubber & 0.01 & 22.91 & 74.84 & 2.23 \\
Others & 5.72 & 0.28 & 79.08 & 14.89 \\
\hline
\end{tabular}


Although the amount of volatile matter was significant, as the waste contains a high moisture content in as received (ar) condition, direct combustion was chosen as the process for energy recovery in the WTE plant instead of gasification. The chlorine contained in the samples was also tested, because chlorine is a source of dioxin, a carcinogen that may be generated in lowtemperature combustion.

Valuable components such as recyclable plastic, paper, electronics, glass, and metal are often selected and taken by informal collectors from TPSs and TPAs, hence the remaining waste consisted only of organic matter, non-recyclable plastic and other wastes, as shown in Table 5. The ultimate, proximate composition and heating value of this remaining waste are shown in Tables 6 and 7. Based on these figures, the combined properties of the remaining waste components (organic matter, food waste, non recyclable plastic, textile, rubber, and miscellaneous) was calculated as follows:

$$
\phi_{\text {comb }}=\sum \varphi_{i} \phi_{i}
$$

where $\varphi_{\text {comp }}=$ any combined element, $\phi_{i}=$ mass fraction of waste component, $\varphi_{i}$ $=$ element $\mathrm{i}$ of the component. The related elements are: ash, moisture, fixed carbon, volatile matter, total carbon, hydrogen, oxygen, nitrogen, and sulfur of the combined remaining waste. The heating value (HHV) was calculated in a similar way. The proximate and ultimate elements of the combined remaining waste components can be seen in Table 8 .

The following equations are used to convert the air-dried based composition to as receive based composition [4]:

$$
\begin{aligned}
& z_{a r}=z_{M A F} \times\left(1-\varphi_{a s h, a r}-\varphi_{M, a r}\right) \\
& z_{M A F}=\frac{z_{a d b}}{1-\varphi_{a s h, a d b}-\varphi_{M, a d b}}
\end{aligned}
$$

where $z_{a r}=$ any properties as received basis, $z_{M A F}=$ any properties moisture and ash free basis, $z_{a d b}=$ any properties air dried basis, $\phi_{a s h}=$ ash mass fraction, $\phi_{M}$ $=$ moisture mass fraction, the subscript $a d b$ indicates air dried basis, while ar indicates as received basis. The proximate and ultimate elements on as received basis can be calculated at various moisture contents by assuming that the ash mass fraction is fixed at $20 \%$, the value that is usually encountered in WTE plants. The fraction of elements with 40 to $60 \%$ moisture content can be seen in Table 9 . 
Table 4 Caloric value and ultimate analysis result of the MSW components.

\begin{tabular}{|c|c|c|c|c|c|c|c|}
\hline Sample Mark & $\begin{array}{c}\text { HHV } \\
\mathrm{kJ} / \mathrm{kg}, \\
\mathrm{adb}\end{array}$ & $\begin{array}{c}\mathrm{C} \\
\%, \\
\mathbf{a d b}\end{array}$ & $\begin{array}{c}\mathbf{H}_{2} \\
\%, \text { adb }\end{array}$ & $\begin{array}{c}\mathrm{N} \\
\%, \text { adb }\end{array}$ & $\begin{array}{c}\mathrm{S} \\
\%, \text { adb }\end{array}$ & $\begin{array}{c}\mathrm{O}_{2} \\
\%, \\
\mathbf{a d b}\end{array}$ & $\begin{array}{c}\text { Cl } \\
\%, \\
\text { adb }\end{array}$ \\
\hline Leaf & 17258 & 42.50 & 5.86 & 0.98 & 0.39 & 42.99 & 0.40 \\
\hline Food waste & 20009 & 45.06 & 6.98 & 2.90 & 0.27 & 40.28 & 2.70 \\
\hline Wood & 15684 & 41.93 & 5.72 & 0.70 & 0.10 & 44.40 & 0.10 \\
\hline Thick Paper & 15165 & 41.72 & 5.95 & 0.07 & 0.11 & 46.75 & 0.07 \\
\hline Writing paper & 12548 & 34.96 & 4.60 & 0.08 & 0.08 & 48.51 & 0.02 \\
\hline Duplex paper & 12297 & 32.68 & 6.20 & 0.12 & 0.12 & 51.34 & 0.12 \\
\hline Box paper & 15474 & 39.00 & 5.70 & 0.45 & 0.16 & 46.25 & 0.08 \\
\hline PVC & 19418 & 36.00 & 4.91 & 0.00 & 0.17 & 53.96 & 3.83 \\
\hline Bottle plastic & 21876 & 62.50 & 4.76 & 0.03 & 0.09 & 32.00 & 0.04 \\
\hline Hard plastic & 23375 & 70.50 & 6.52 & 0.45 & 0.08 & 22.04 & 0.06 \\
\hline Wrapping plastic & 31041 & 60.55 & 7.53 & 0.11 & 0.23 & 28.04 & 3.82 \\
\hline Toy plastic & 44966 & 87.23 & 7.71 & 0.01 & 0.08 & 3.27 & 0.04 \\
\hline PP plastic & 45770 & 85.71 & 13.15 & 0.04 & 0.07 & 0.37 & 0.06 \\
\hline OPP plastic & 45766 & 84.01 & 12.66 & 0.01 & 0.11 & 3.03 & 0.03 \\
\hline Container plastic & 44795 & 83.81 & 10.05 & 0.06 & 0.01 & 4.49 & 0.08 \\
\hline HD plastic & 45586 & 72.30 & 11.33 & 0.02 & 0.13 & 15.81 & 0.02 \\
\hline Syringe & 45653 & 83.60 & 11.10 & 0.04 & 0.09 & 4.48 & 0.07 \\
\hline PE plastic & 46084 & 83.75 & 13.08 & 0.05 & 0.08 & 2.63 & 0.06 \\
\hline Plastic bag & 45008 & 89.95 & 5.68 & 0.07 & 0.10 & 2.45 & 0.04 \\
\hline Medical plastic & 45644 & 83.93 & 13.70 & 0.03 & 0.09 & 1.88 & 0.04 \\
\hline Plastic cup & 46143 & 81.22 & 15.33 & 0.04 & 0.07 & 33.21 & 0.12 \\
\hline Styrofoam & 38359 & 91.35 & 6.49 & 0.07 & 0.14 & 1.11 & 0.02 \\
\hline Synthetic waste & 21956 & 45.72 & 6.67 & 1.45 & 0.39 & 30.80 & 3.85 \\
\hline Waste sample I & 14712 & 27.80 & 3.18 & 0.92 & 0.23 & 41.10 & 0.08 \\
\hline Waste sample II & 11045 & 24.33 & 10.78 & 0.55 & 0.16 & 55.20 & 0.10 \\
\hline Textile & 18774 & 52.54 & 5.69 & 0.44 & 0.21 & 40.71 & 0.03 \\
\hline Rubber & 28948 & 45.72 & 6.67 & 1.45 & 0.39 & 30.80 & 3.85 \\
\hline Others & 22588 & 42.25 & 5.79 & 0.84 & 0.25 & 43.69 & 0.10 \\
\hline
\end{tabular}

Table 5 Composition of the remaining MSW.

\begin{tabular}{lcc}
\hline \multicolumn{1}{c}{ Component } & $\begin{array}{c}\text { Mass } \\
\text { Fraction }\end{array}$ & Volume Fraction \\
\hline Organic matter & 49.24 & 68.22 \\
Food Waste & 31.23 & 18.00 \\
Non Recycled Plastic & 8.21 & 7.85 \\
Textile & 2.83 & 1.42 \\
Rubber & 0.92 & 0.55 \\
Others & 7.57 & 3.96 \\
\hline
\end{tabular}


Table 6 Proximate analysis result of the remaining MSW components.

\begin{tabular}{lcccc}
\hline \multicolumn{1}{c}{ Component } & $\begin{array}{c}\text { Moisture } \\
\text { \%, adb }\end{array}$ & $\begin{array}{c}\text { Ash } \\
\boldsymbol{\%}, \mathbf{a d b}\end{array}$ & $\begin{array}{c}\text { Volatile } \\
\text { Matter } \\
\mathbf{\%}, \mathbf{a d b}\end{array}$ & $\begin{array}{c}\text { Fixed } \\
\text { Carbon } \\
\boldsymbol{\%}, \mathbf{a d b}\end{array}$ \\
\hline Organic matter & 9.80 & 7.215 & 64.45 & 18.53 \\
Food waste & 8.48 & 4.51 & 72.52 & 14.49 \\
Non-recycled plastic & 0.88 & 2.19 & 93.25 & 3.67 \\
Textile & 1.23 & 0.42 & 89.07 & 9.28 \\
Rubber & 4.78 & 14.55 & 72.55 & 7.72 \\
Others & 0.71 & 5.70 & 79.10 & 14.49 \\
\hline
\end{tabular}

Table 7 Caloric value and ultimate analysis result of the remaining MSW components.

\begin{tabular}{|c|c|c|c|c|c|c|c|}
\hline Sample Mark & $\begin{array}{c}\text { HHV } \\
\mathrm{kJ} / \mathrm{kg}, \\
\mathrm{adb}\end{array}$ & $\begin{array}{c}\mathrm{C} \\
\%, \\
\mathrm{adb}\end{array}$ & $\begin{array}{c}\mathrm{H}_{2} \\
\%, \\
\text { adb }\end{array}$ & $\begin{array}{c}\mathbf{N} \\
\%, \\
\text { adb }\end{array}$ & $\begin{array}{c}\mathrm{S} \\
\%, \\
\mathrm{adb}\end{array}$ & $\begin{array}{c}\mathbf{O}_{2} \\
\%, \\
\text { adb }\end{array}$ & $\begin{array}{c}\mathrm{Cl} \\
\%, \\
\text { adb }\end{array}$ \\
\hline Organic matter & 16446 & 42.22 & 5.79 & 0.84 & 0.25 & 43.69 & 0.25 \\
\hline Food waste & 20003 & 45.06 & 6.98 & 2.90 & 0.27 & 40.28 & 2.70 \\
\hline $\begin{array}{l}\text { Non-recycled } \\
\text { Plastic }\end{array}$ & 34691 & 75.95 & 7.01 & 0.09 & 0.18 & 14.57 & 1.92 \\
\hline Textile & 18769 & 52.54 & 5.69 & 0.44 & 0.21 & 40.70 & 0.03 \\
\hline Rubber & 25445 & 45.72 & 6.67 & 1.45 & 0.39 & 30.80 & 3.85 \\
\hline Others & 22582 & 54.41 & 6.59 & 1.28 & 0.23 & 32.85 & 0.21 \\
\hline
\end{tabular}

Table 8 Proximate and ultimate analysis result of the remaining MSW components.

\begin{tabular}{lrlr}
\hline \multicolumn{1}{c}{ Proximate } & \multicolumn{2}{c}{ Ultimate } \\
\hline Component & $\%$ & Component & $\%$ \\
Volatile matter & 71.19 & Carbon & 48.46 \\
Fixed carbon & 15.41 & Oxygen & 41.98 \\
Moisture & 8.04 & Hydrogen & 6.58 \\
Ash & 5.36 & Nitrogen & 1.49 \\
& & Chlorine & 1.23 \\
& & Sulphur & 0.26 \\
\hline
\end{tabular}

From Table 9 it can be seen that the sulfur content is less than $0.1 \%$, which is lower compared to the average sulfur content in coal $(0.7 \%)$ [5]. The chlorine content of waste fuel is less than $0.5 \%$; this value is higher compared to the chlorine content in coal $(0.3 \%)$ [6] but still within the range of biomass fuels [7]. The sulfur and chlorine contents are harmless concentrations because they are smaller than $0.3 \%$ and $1.0 \%$ respectively [8]. 
Table 9 Prediction of element composition of remaining waste on as receive basis (ar).

\begin{tabular}{lccc}
\hline \multicolumn{1}{c}{ Element } & \multicolumn{3}{c}{ Mass Fraction $(\%)$} \\
\cline { 2 - 4 } \multicolumn{1}{c}{ Moisture } & $\mathbf{4 0 . 0}$ & $\mathbf{5 0 . 0}$ & $\mathbf{6 0 . 0}$ \\
\hline Carbon $(\mathrm{C})$ & 19.38 & 14.54 & 9.69 \\
Hydrogen $\left(\mathrm{H}_{2}\right)$ & 2.63 & 1.97 & 1.32 \\
Nitrogen $(\mathrm{N})$ & 0.59 & 0.45 & 0.30 \\
Sulfur $(\mathrm{S})$ & 0.10 & 0.08 & 0.05 \\
Oxygen $(\mathrm{O})$ & 16.80 & 12.60 & 8.40 \\
Chlorine $(\mathrm{Cl})$ & 0.49 & 0.37 & 0.25 \\
Ash & 20.0 & 20.0 & 20.0 \\
\hline
\end{tabular}

The heating values obtained from the tests were air dried basis (adb) values $\left(H H V_{a d b}\right)$. These values have to be changed to as received basis (ar) values $\left(H H V_{a r}\right)$ and they can be calculated from:

$$
\begin{aligned}
& H H V_{a r}=H H V_{M A F} \times\left(\varphi_{F C}+\varphi_{V M}\right) \\
& H H V_{M A F}=\frac{H H V_{a d b}}{1-\varphi_{a s h}}
\end{aligned}
$$

where $\phi_{F C}=$ mass fraction of the fixed carbon and $\phi_{V M}=$ mass fraction of the volatile matter, $H H V_{M A F}=$ heating value in moisture and ash free condition, $\phi_{a s h}$ $=$ mass fraction of the ash. The as received basis low heating value $\left(L H V_{a r}\right)$ is then calculated from:

$$
L H V_{a r}=H H V_{a r}-Q_{H_{2} O}
$$

where:

$$
Q_{\mathrm{H}_{2} \mathrm{O}}=Q_{1}+Q_{2}
$$

$Q_{1}=$ heat to evaporate moisture within the fuel:

$$
Q_{1}=\varphi_{M} \times h_{f g}
$$

$Q_{2}=$ heat to evaporate water that is formed from the combustion reaction of the hydrogen:

$$
Q_{2}=9 \times \varphi_{H} \times h_{f g}
$$

with $\phi_{M}=$ mass fraction of the moisture within the fuel, $\phi_{H}=$ mass fraction of the hydrogen within the fuel, and $h_{f g}=$ latent heat of evaporation at $100^{\circ} \mathrm{C}$, 
$2257 \mathrm{~kJ} / \mathrm{kg}$. The heating value $L H V_{a r}$ for different values of moisture content can be seen in Figure 1.

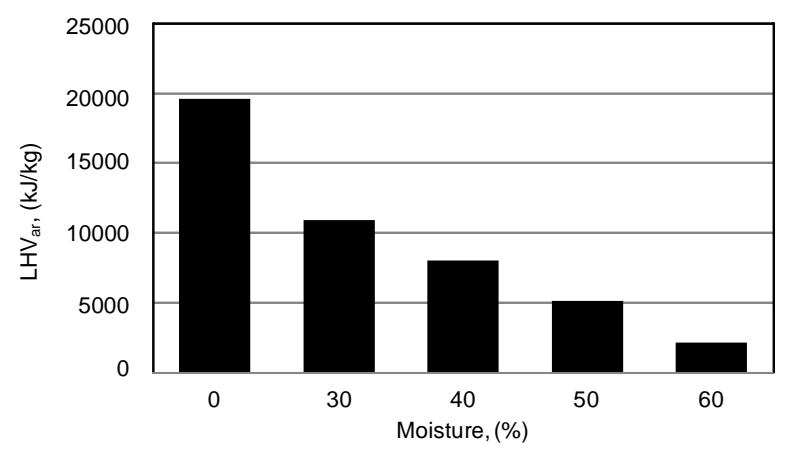

Figure 1 Variation of waste heating value with moisture content.

From Figure 1 it can be seen that the heating value is strongly influenced by the moisture content. For the waste to be burned without using additional fuel, the moisture content should be lower than $50 \%$, the ash content lower than $60 \%$, and the fixed carbon content larger than $25 \%$ [9]. This condition is shown by the shaded area in Figure 2. Since the actual moisture content in fresh tropical MSW can reach 60 to $70 \%$, the waste has to be pre-treated before it can be burned in a furnace. For a moisture content of $40 \%$ the heating value (LHV) of the waste is around $1500 \mathrm{kcal} / \mathrm{kg}(6000 \mathrm{~kJ} / \mathrm{kg})$. This heating value and its related ultimate elements composition were used in the design of a WTE plant.

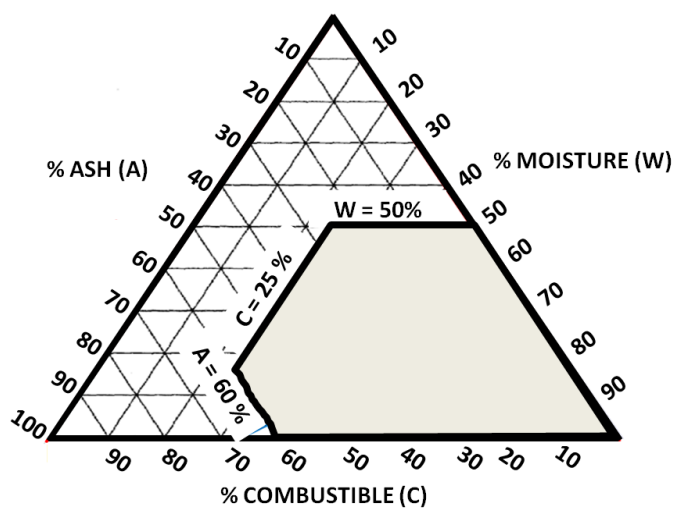

Figure 2 Tanner diagram for waste combustion [8]. 


\section{Waste to Energy Plant}

A small WTE plant concept is shown in Figure 3; the waste collected from the city is dumped into a ditch where informal collectors can select recycleable materials. Then the remaining waste is chopped in a chopping machine and distributed by a dozer on the drying floor. The WTE plant is planned to be located close to a TPA. The waste is air-dried for several days before it is sent to the furnace by a belt conveyor system, so that the moisture content drops below $40 \%$. The waste is self-burned in the furnace at a temperature above 850 ${ }^{\circ} \mathrm{C}$. The flue gas is used to generate steam in a boiler for electric power generation. The flue gas is treated and conditioned before it is released to the surrounding air through a stack.

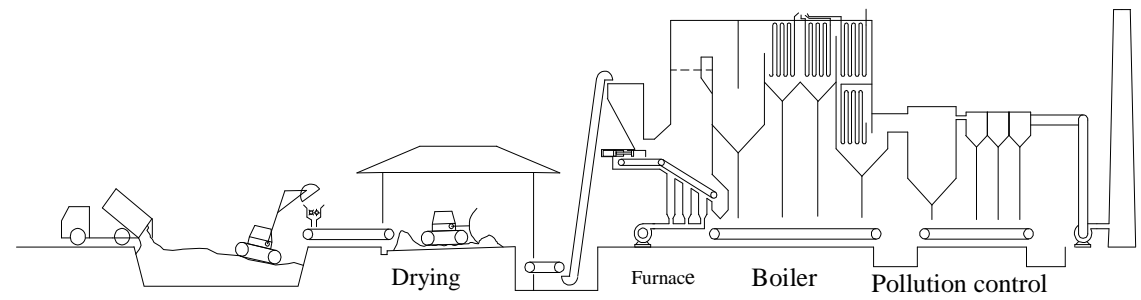

Figure 3 A small-scale Waste to Energy plant concept.

The operating conditions of the steam power plant were simulated using the Cycle Tempo software application. The input for the program was the technical specification of a commercial turbine, as shown in Table 10. Assumptions used in the simulation were: $85 \%$ of turbine isentropic efficiency, $75 \%$ of pump isentropic efficiency, $28^{\circ} \mathrm{C}$ ambient temperature, $76 \%$ of relative humidity of the surrounding air, and saturated vapor at the outlet of the turbine. The simulations were done for a water-cooled and an air-cooled condenser; the results are shown in Figure 4, and a summary of the results is shown in Table 11.

Table 10 Steam turbine specification.

\begin{tabular}{ll}
\hline \multicolumn{1}{c}{ Parameter } & \multicolumn{1}{c}{ Value } \\
\hline Power & $800 \mathrm{~kW}$ \\
Steam mass flow rate & $1.149 \mathrm{~kg} / \mathrm{s}$ \\
Inlet temperature & $340{ }^{\circ} \mathrm{C}$ \\
Inlet pressure & $13 \mathrm{bar}$ \\
Extraction Pressure & $1.71 \mathrm{bar}$ \\
Extraction steam mass flow rate & $0.134 \mathrm{~kg} / \mathrm{s}$ \\
Outlet pressure & $0.1 \mathrm{bar}$ \\
\hline
\end{tabular}




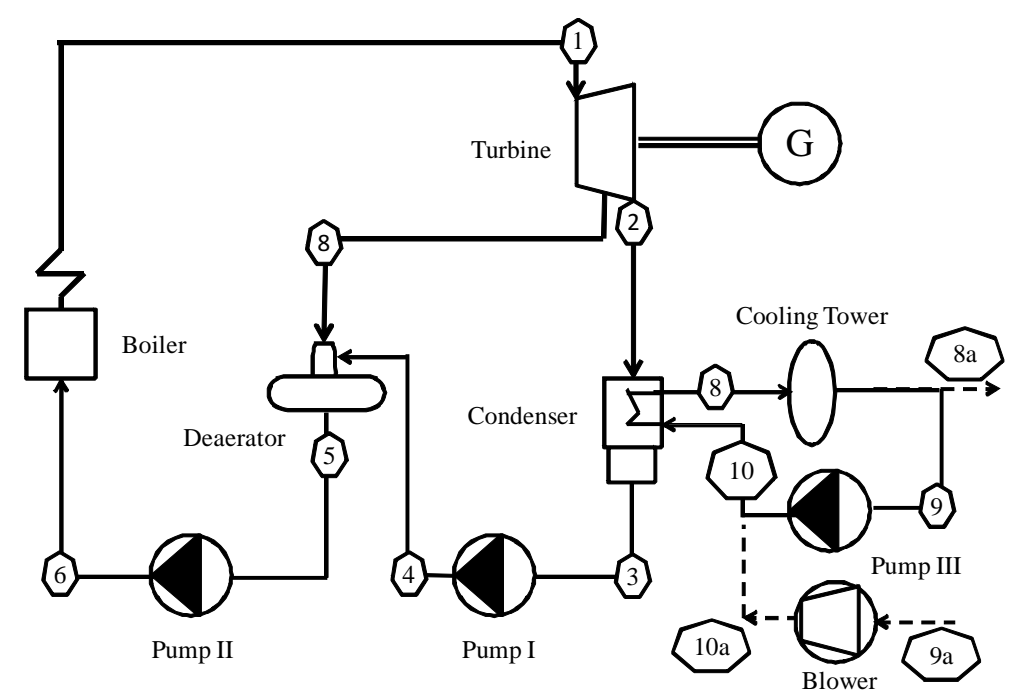

\begin{tabular}{ccccccc}
\hline \multirow{2}{*}{ Station } & \multicolumn{3}{c}{ Water-cooled condenser } & \multicolumn{3}{c}{ Air-cooled condenser } \\
& $\mathbf{P}(\mathbf{k P a})$ & $\mathbf{T}\left({ }^{\circ} \mathbf{C}\right)$ & $\mathbf{m}(\mathbf{k g} / \mathbf{s})$ & $\mathbf{P}(\mathbf{k P a})$ & $\mathbf{T}\left({ }^{\circ} \mathbf{C}\right)$ & $\mathbf{m}(\mathbf{k g} / \mathbf{s})$ \\
\hline 1 & 1300.0 & 340 & 1.149 & 1300.0 & 340 & 1,149 \\
2 & 10 & 45.81 & 1.019 & 10 & 45.81 & 1.019 \\
3 & 10 & 45.81 & 1.019 & 10 & 45.81 & 1.019 \\
4 & 171.0 & 45.83 & 1.019 & 171.0 & 45.83 & 1.019 \\
5 & 171.0 & 115.3 & 1.149 & 171.0 & 115.3 & 1.149 \\
6 & 1300.0 & 115.5 & 1.149 & 1300.0 & 115.5 & 1.149 \\
7 & 171.0 & 146.84 & 0.13 & 171.0 & 146.84 & 0.130 \\
8 & 151.3 & 38.01 & 53.71 & & & \\
9 & 101.2 & 28.00 & 53.71 & & & \\
10 & 201.3 & 28.01 & 53.71 & & & \\
$8 \mathrm{a}$ & & & & 102.3 & 40.00 & 225.08 \\
$9 \mathrm{a}$ & & & & 101.3 & 28.00 & 225.08 \\
$10 \mathrm{a}$ & & & & 103.3 & 30.24 & 225.08 \\
\hline
\end{tabular}

Figure 4 Process diagram of WTE Plant.

Table 11 Summary of simulation.

\begin{tabular}{lrr}
\hline \multicolumn{1}{c}{ Item } & Water cooled & Air cooled \\
\hline Heat in boiler, kW & 3040 & 3040 \\
Gross turbine power, kW & 800 & 800 \\
Pump I work, kW & 0.37 & 0.38 \\
Pump II work, kW & 2.55 & 2.56 \\
Pump III/Blower work, kW & 8.93 & 547.3 \\
Net power, kW & 788 & 249 \\
Thermal efficiency (\%) & 25.92 & 8.21 \\
\hline
\end{tabular}


From the simulation results it can be seen that a small steam power plant can be fueled by the remaining waste from the MSW. Using a small steam turbine with extraction for an open type feed water heater (de-aerator), the plant produces $800 \mathrm{~kW}$ power. The system is a closed system using a low-pressure condenser. A water-cooled condenser system produces a much higher net power compared to an air-cooled system. An air blower consumes a high power and reduces the net power output and thermal efficiency of the system.

The Cycle Tempo simulation results were used as the input for a furnace and boiler simulation. The FireCad software application was used for the simulation. The input and assumptions were: $4136.4 \mathrm{~kg} / \mathrm{hour}$ steam mass flow rate, 13 bar of water pressure entering the boiler, water entering the boiler with a temperature of $115{ }^{\circ} \mathrm{C}$, and a steam temperature at the Super-heater outlet of $340^{\circ} \mathrm{C}$, a flue-gas temperature leaving the stack of $180^{\circ} \mathrm{C}, 80 \%$ excess air in the furnace, $20 \%$ flue gas return (FGR), and waste-element composition used in the simulation as shown in Table 11. The FireCad simulation results were checked by re-inputting them into Cycle Tempo until convergence of steam mass flow rate and boiler heat load was reached. A summary of the results is shown in Table 12. The results show that the waste mass flow rate is $2040 \mathrm{~kg} / \mathrm{hour}$ or around 2 ton/h if the WTE operates 24 hours a day, 4.2 ton/h of steam and 800 $\mathrm{kW}$ of electric power will be generated. The resulted main dimensions of the furnace and boiler are shown in Tables 13 to 16.

Table 12 Element composition of waste used in FireCad simulation (without chlorine).

\begin{tabular}{lc}
\hline \multicolumn{1}{c}{ Element } & Mass Fraction $(\%)$ \\
\hline Carbon & 19.63 \\
Hydrogen & 2.66 \\
Nitrogen & 0.60 \\
Sulphur & 0.11 \\
Oxygen & 17.0 \\
Ash & 20.00 \\
Moisture & 40.00 \\
\hline
\end{tabular}

The tables show that the furnace temperature reaches $900^{\circ} \mathrm{C}$ and the gas residence time is longer than 2 seconds, which fulfills the requirement for dioxin destruction [10-12]. The resulted dimensions have been checked manually and can be used for further designing of the plant. 
Table 13 Summary results of FireCad simulation.

\begin{tabular}{lr}
\hline \multicolumn{1}{c}{ Parameter } & \multicolumn{1}{c}{ Value } \\
\hline Steam generated, kg/hour & 4136.4 \\
Steam pressure, bar & 13 \\
Excess air, \% & 80.0 \\
FGR, \% & 20.0 \\
Boiler efficiency & 79.27 \\
Waste mass flow rate, kg/hour & 2040.62 \\
LHV waste, kJ/kg & 6521.094 \\
Boiler heat load, kW & $3051 \mathrm{~kW}$ \\
\hline
\end{tabular}

Table 14 Furnace main dimensions.

\begin{tabular}{lrr}
\hline \multicolumn{1}{c}{ Parameter } & Value & \multicolumn{1}{c}{ Unit } \\
\hline Flue gas mass flowrate & 12843,2 & $\mathrm{~kg} / \mathrm{hour}$ \\
Flue gas volumetric rate & 45020.2 & $\mathrm{~m} 3 / \mathrm{hour}$ \\
Flue gas velocity & 7.0 & $\mathrm{~m} / \mathrm{s}$ \\
Furnace width & 1.446 & $\mathrm{~m}$ \\
Furnace depth & 1.221 & $\mathrm{~m}$ \\
Furnace height & 19.0 & $\mathrm{~m}$ \\
Gas residence time & 2.67 & $\mathrm{~S}$ \\
Gas temperature & 915.5 & ${ }^{\circ} \mathrm{C}$ \\
\hline
\end{tabular}

Table 15 Superheater main dimensions.

\begin{tabular}{lrr}
\hline \multicolumn{1}{c}{ Parameter } & Value & Unit \\
\hline Pipe diameter & 50.8 & $\mathrm{~mm}$ \\
Pipe thickness & 4.0 & $\mathrm{~mm}$ \\
Pipe length & 5.36 & $\mathrm{~m}$ \\
Transversal pitch & 154.0 & $\mathrm{~mm}$ \\
Longitudinal pitch & 154.0 & $\mathrm{~mm}$ \\
Umber of pipe pass & 3 & - \\
Number of pipe each row & 4 & - \\
Heat load & 507 & $\mathrm{~kW}$ \\
Heat transfer area & 10.26 & $\mathrm{~m}^{2}$ \\
Steam outlet temperature & 386.28 & ${ }^{\circ} \mathrm{C}$ \\
Gas temperature outlet & 864.9 & ${ }^{\circ} \mathrm{C}$ \\
Overall heat transfer & 39.0 & $\mathrm{~W} / \mathrm{m}^{2} \mathrm{~K}$ \\
coefficient (U) &
\end{tabular}


Table 16 Boiler bank main dimensions.

\begin{tabular}{lrr}
\hline \multicolumn{1}{c}{ Parameter } & Value & Unit \\
\hline Pipe diameter & 50.8 & $\mathrm{~mm}$ \\
Pipe thickness & 3.66 & $\mathrm{~mm}$ \\
Pipe length & 461 & $\mathrm{~m}$ \\
Transversal pitch & 105 & $\mathrm{~mm}$ \\
Longitudinal pitch & 100 & $\mathrm{~mm}$ \\
Number of pipe pass & 22 & - \\
Number of pipe each row & 13 & - \\
Heat transfer area & 210.23 & $\mathrm{~m} 2$ \\
Steam outlet temperature & 199.18 & ${ }^{\circ} \mathrm{C}$ \\
Gas temperature outlet & 326.42 & ${ }^{\circ} \mathrm{C}$ \\
Overall heat transfer & 35.26 & $\mathrm{~W} / \mathrm{m}^{2} \mathrm{~K}$ \\
coefficient (U) & &
\end{tabular}

\section{Conclusion}

Based on the analysis results discussed above, it can be concluded that tropical municipal solid waste (MSW) can be used as a steam power plant fuel without using additional oil or solid fuel, even if recyclable components have been removed. The existing moisture content of the MSW is larger than $60 \%$, so a pre-treatment process has to be applied to reduce the moisture content to 40$50 \%$. The waste with a moisture content of $40 \%$ will have a heating value of $6500 \mathrm{~kJ} / \mathrm{kg}$ or $1500 \mathrm{kcal} / \mathrm{kg}$ (LHV) on as received basis. Using the waste with a moisture content of $40 \%$, a small WTE plant can be designed that can deliver $800 \mathrm{~kW}$ electric power from 50 tonnes/day or $2.04 \mathrm{~kg} / \mathrm{hr}$ of waste. A WTE with an air-cooled condenser produces less power output and has lower thermal efficiency. The cycle simulation result data can be used for the design of a furnace and boiler. The results show that the waste may generate enough heat to maintain the furnace temperature at around $900^{\circ} \mathrm{C}$ and the gas residence time is longer than 2 seconds, as required for dioxin destruction.

\section{Nomenclature}

$\begin{array}{ll}h_{f g} & =\text { latent heat of evaporation } \\ H H V & =\text { higher heating value } \\ L H V & =\text { lower heating value } \\ M & =\text { mass flow rate } \mathrm{kg} / \mathrm{s} \\ M S W & =\text { municipal solid waste } \\ P & =\text { pressure, } \mathrm{kPa} \\ T & =\text { temperature in }{ }^{\circ} \mathrm{C} \\ W T E & =\text { Waste-to-Energy } \\ z_{a r} & =\text { any properties on as receive basis }\end{array}$




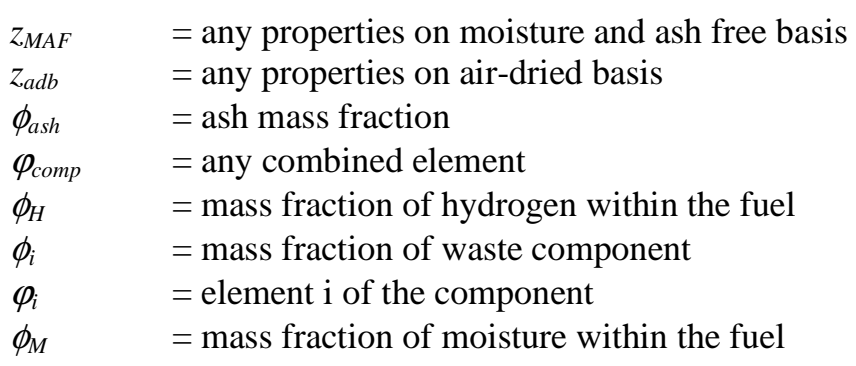

\section{References}

[1] UNFCCC/CCNUCC, CDM Executive Board AM0025 Version 07 Sectoral Scope $01 \& 13, \quad$ EB31, http://cdm.unfccc.int/EB/031/ eb31_repan05.pdf, (31 May 2007).

[2] Cycle-Tempo, TU Delft, www.cycle-tempo.nl, (25 May 2006).

[3] FireCad Technologies, www.firecad.net, (25 May 2006).

[4] Rand, T., Haukohl, J. \& Marxen, U., Municipal Solid Waste Incineration, Requirements for a Successful Project, World Bank Technical Paper No.462, The International Bank for Reconstruction and Development, Washington D.C., 2000.

[5] The Ministry for Environment and Local Government Republic of Ireland, Agreement between The Solid Fuel Trade Group and The Minister for The Environment and Local Government Concerning A Reduction In The Sulphur Content of Bituminous Coal and Petcoke and The Extension Of The Ban on The Marketing, Sale and Distribution of Solid Fuels, June 2002, Ireland. http://www.environ.ie/en/Publications/ Environment/Atmosphere/FileDownLoad,948,en.pdf, (25 February 2009).

[6] Thomas, L., Coal Technology, John Wiley \& Son, 2002.

[7] Duong, D.N.B. \& Tillman, D.A., Chlorine Issues with Biomass Cofiring in Pulverized Coal Boilers: Sources, Reactions, and Consequences - A Literature Review, Foster Wheeler Publication, May 2009, http://www.fwc.com/publications/tech_papers/files/TP_PC_09_ 01.pdf, (25 August 2009).

[8] Babcock and Wilcox, Steam Its Generation and Use, 40th edition, The Babcock and Wilcox Company, USA, 1992.

[9] Hewitt, G.F., Shires G.L. \& Bott, T.R., Process Heat Transfer, Begell House, Inc., New York, 2000.

[10] World Health Organization, Dioxin and Their Effect to Human, Fact Sheet No: 225, May 2010. http://www.who.int/mediacentre/factsheets/ fs225/en, (12 August 2010).

[11] Baun, D.L., Dioxin Generation and Regeneration In Modern Energy Recovery Plants, Iswa $6^{\text {th }}$ Beacon Conference, Nov. 2009, http://www. 
beacon-wte.net/fileadmin/avfallsverige/Documentation_2009/D_Laerke _Baun.pdf, (12 August 2010).

[12] Clarke, M.J., Introduction to Municipal Solid Waste Incineration, Air and Waste Management Association Annual Meeting Baltimore, MD, June 23-27, 2002, http://www.geo.hunter.cuny.edu/ mclarke/IntroMS Wincineration.htm, (12 August 2010). 